\title{
The effect of body armour and load carriage on respiratory function and exercise
}

\author{
Nicola Armstrong ${ }^{1 *}$, Amanda Ward², Gilbert Chanza ${ }^{2}$, Mitch Lomax², Michael J Tipton², James R House ${ }^{2}$ \\ From 15th International Conference on Environmental Ergonomics (ICEE XV) \\ Portsmouth, UK. 28 June - 3 July 2015
}

\section{Introduction}

Wearing body armour (BA) causes a restrictive respiratory defect, which is caused by its increased mass and restriction of chest expansion [1,2]. The evidence suggests that this respiratory impairment is sufficient to reduce maximal exercise capacity and may result in the early onset of fatigue [3]. This study tested the hypothesis that UK military BA and load carriage would impair respiratory function at rest and during military patrolling tasks.

\section{Methods}

24 male military participants completed a laboratory test five times wearing no BA, BA alone (total mass $15 \mathrm{~kg}$ ), $\mathrm{BA}+15 \mathrm{~kg}(30 \mathrm{~kg}), \mathrm{BA}+25 \mathrm{~kg}(40 \mathrm{~kg})$ or $\mathrm{BA}+35 \mathrm{~kg}$ $(50 \mathrm{~kg})$. The laboratory test involved measurements of pulmonary function at rest (e.g. flow volume loops) and during a continuous treadmill test (e.g. tidal flow volume loop measurement during exercise). The speed and incline (\%) of the treadmill was increased every ten minutes to represent the following military tasks; a cautious patrol (light exercise: $3 \mathrm{~km} \cdot \mathrm{h}^{-1}, 0 \%$ ), low threat patrol (moderate exercise: $4 \mathrm{~km} \cdot \mathrm{h}^{-1}, 3 \%$ ), forced march (heavy exercise: $5 \mathrm{~km} \cdot \mathrm{h}^{-1}, 4 \%$ ) and contact situation (very heavy exercise: $6 \mathrm{~km} \cdot \mathrm{h}^{-1}, 5 \%$ ). Respiratory muscle pressures (RMP) were also measured pre and post exercise.

\section{Results}

BA caused a mild (6\% to $8 \%$ ) restrictive respiratory impairment (a reduction in $\mathrm{FVC}$ and $\mathrm{FEV}_{1}$ without a reduction in $\mathrm{FEV}_{1} / \mathrm{FVC}$ ). This restriction increased to $15 \%$ with the addition of $35 \mathrm{~kg}$. A reduction in RMP was observed in all conditions immediately post exercise $(11 \%$ to $18 \%$ for inspiratory muscles and $16 \%$ to $23 \%$ for

\footnotetext{
* Correspondence: ncarmstrong@dstl.gov.uk

'Dstl, Human Systems Group, Porton Down, Salisbury, UK

Full list of author information is available at the end of the article
}

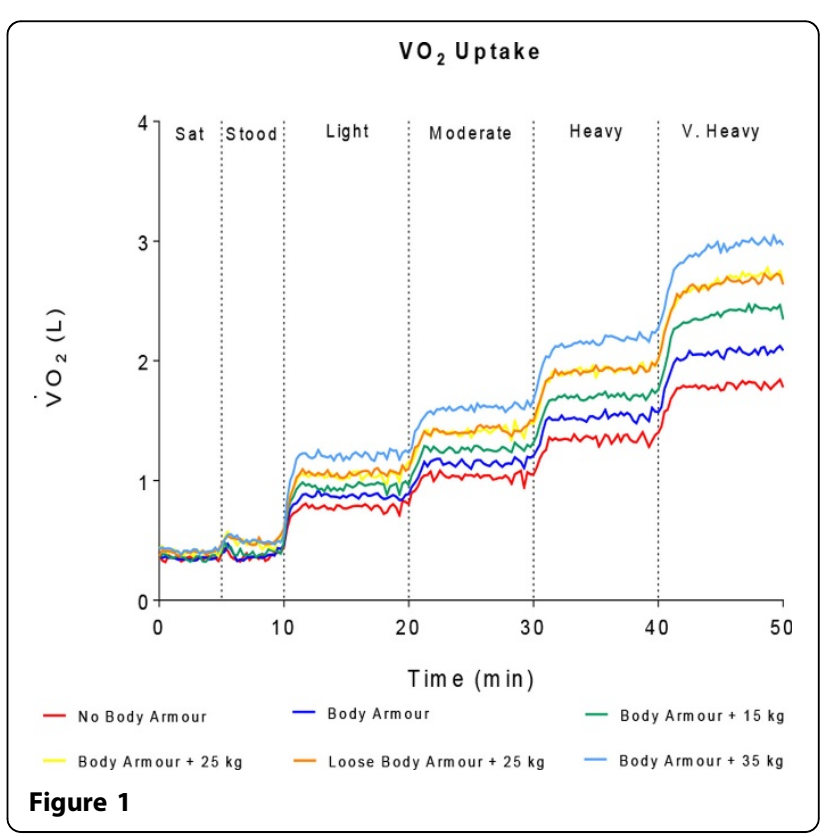

expiratory muscles). At five minutes post exercise, RMP returned to baseline levels when no BA was worn and also when BA was worn without additional load. Respiratory limitation was observed during very heavy exercise in the loaded conditions (where exercise tidal flows meet the maximum flow volume loop envelope). Energy expenditure was defined for five loads and four exercise intensities (see Figure 1). At each exercise intensity, increases in ventilation caused by wearing BA and load were explained by increases in breathing frequency.

\section{Discussion}

This study has quantified the respiratory burden associated with carrying BA with loads up to $50 \mathrm{~kg}$. A restrictive respiratory impairment was observed with $\mathrm{BA}$ and load carriage. Reductions in RMP are indicative of 
respiratory muscle fatigue and suggest that longer periods of recovery would be required between tasks when BA is worn with load.

\section{Conclusion}

UK military soldiers may experience respiratory limitation during patrolling tasks. This may reduce exercise capacity and lead to the early onset of fatigue [3]. These findings have implications for military task performance e.g. marksmanship and fire and movement, where stable breathing patterns and quick recovery times are essential.

\section{Authors' details}

${ }^{1}$ Dstl, Human Systems Group, Porton Down, Salisbury, UK. 'Extreme Environments Laboratory, Department of Sport and Exercise Science, University of Portsmouth, Portsmouth, UK.

Published: 14 September 2015

\section{References}

1. Legg SJ: Influence of Body Armour on Pulmonary Function. Ergonomics 1988, 31(3):349-353.

2. Bygrave S, Legg SJ, Myers S, Llewwllyn M: Effect of Backpack Fit on Lung Function. Ergonomics 2004, 47:324-329.

3. Coast JR, Cline CC: The Effect of Chest Wall Restriction on Exercise Capacity. Respirology 2004, 9(2):197-203.

doi:10.1186/2046-7648-4-S1-A84

Cite this article as: Armstrong et al.: The effect of body armour and load carriage on respiratory function and exercise. Extreme Physiology \& Medicine 2015 4(Suppl 1):A84

\section{Submit your next manuscript to BioMed Central} and take full advantage of:

- Convenient online submission

- Thorough peer review

- No space constraints or color figure charges

- Immediate publication on acceptance

- Inclusion in PubMed, CAS, Scopus and Google Scholar

- Research which is freely available for redistribution

Submit your manuscript at www.biomedcentral.com/submit 